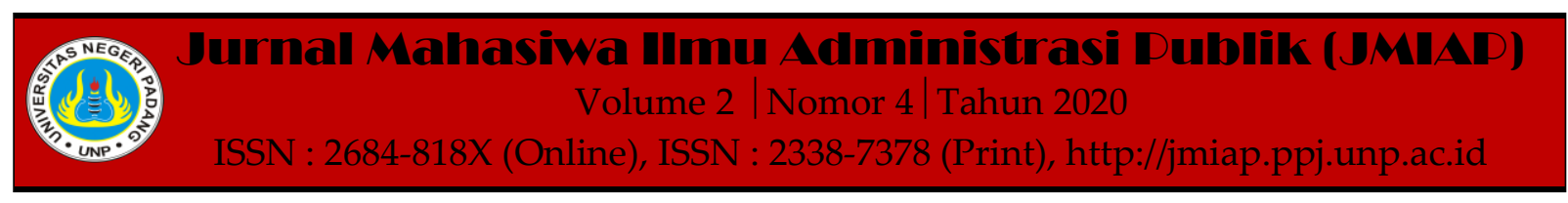

\title{
IMPLEMENTASI STRATEGI DINAS PARIWISATA PEMUDA DAN OLAHRAGA DALAM MENGEMBANGKAN EKONOMI KREATIF DI KOTA SAWAHLUNTO
}

\author{
Sri Wahyuni ${ }^{1(\mathrm{a})}$, Afriva Khaidir ${ }^{2(\mathrm{~b})}$ \\ ${ }^{1}$ Jurusan Ilmu Administrasi Negara, Universitas Negeri Padang \\ ${ }^{2}$ Jurusan Ilmu Administrasi Negara, Universitas Negeri Padang \\ a)sriwahyuni10090@gmail.com, b)af.khaidir@ fis.unp.ac.id
}

\begin{abstract}
This study describes the implementation of the strategy of the Tourism, Youth and Sports Office in developing the creative economy in Sawahlunto City. The background of this research is because several problems were found in the development of the creative economy in Sawahlunto, namely, human resource development is not optimal, capital is still limited, product marketing is still limited. The formulation of the problem in this study is how the implementation of the strategy of the Tourism, Youth and Sports Office in developing the creative economy in Sawahlunto City and what factors affect the implementation of the creative economy development strategy in Sawahlunto City. This research was conducted using descriptive qualitative methods. The selection of informants was carried out by using purposive sampling technique. Test the validity of the data using the triangulation technique. Data collection was carried out by means of interviews and documentation studies. The data were analyzed by means of data reduction, data presentation, data verification. The results show that the implementation of the strategy of the Tourism, Youth and Sports Office can be said to have been carried out well, although in its development there are still shortcomings and obstacles faced.
\end{abstract}

Keywords : Implementation, Strategy, Development, Creative Economy

Corresponding author. Email. sriwahyuni10090@gmail.com

How to cite this article. Wahyuni, Sri \& Khaidir, Afriva. (2020). Implementasi Strategi Dinas Pariwisata Pemuda dan Olahraga dalam Mengembangkan Ekonomi Kreatif di Kota Sawahlunto. Jurnal Mahasiwa Ilmu Administrasi Publik (JMIAP) Jurusan Ilmu Administrasi Negara Fakultas Ilmu Sosial Universitas Negeri Padang, Volume 2 (4), Hal. 20-27.

http://jmiap.ppj.unp.ac.id

ISSN : 2684-818X (Online), ISSN : 2338-7378 (Print)

Copyright@2020. Published by Labor Jurusan Ilmu Administrasi Negara FIS UNP, Padang 


\section{PENDAHULUAN}

Ekonomi kreatif merupakan konsep ekonomi di era ekonomi baru yang bertumpu pada cadangan pemikiran dan Pengetahuan sumber daya manusia merupakan faktor produksi utama dari kegiatan ekonomi (Kemendag, 2009). Ekonomi kreatif dipercaya bisa mempercepat proses pembangunan ekonomi dan pembangunan komersial. Hal tersebut merupakan fenomena yang didasarkan pada perkembangan ekonomi dan pengalaman perkembangan bisnis di banyak negara, terutama berdasarkan perbedaan yang sangat besar dalam Kinerja pembangunan ekonomi dan bisnis antara negara yang sumber daya alamnya lemah dan negara dengan kekayaan alam yang kaya.

Kunci sukses pembangunan ekonomi dan pengembangan bisnis terletak pada sumber daya manusia yang sangat baik yang dibutuhkan untuk membangun ekonomi kreatif. Fokus pemerintah di bidang ekonomi kreatif dimulai sejak tahun 2006 ketika ditunjuk oleh Kementerian Perdagangan, Perindustrian dan Pariwisata akan mengawasi perkembangan ekonomi kreatif melalui Rancangan Indonesia Power Plan 2006-2010 yang tujuannya untuk meningkatkan daya saing ekspor produk Indonesia di pasar dalam dan luar negeri, tetapi bercirikan nasional. Selain itu, pada tahun 2011 ekonomi kreatif masuk dalam klasifikasi Kementerian Pariwisata karena ekonomi kreatif dinilai sangat erat kaitannya dengan pariwisata.

Berdasarkan Peraturan Presiden No 72 Th 2015 (perubahan Peraturan Presiden Nomor 6 Biro Ekonomi Kreatif), terdiri dari 16 jenis, yaitu: 1) periklanan, 2) arsitektur, 3) kesenian, 4) kerajinan , 5) desain , 6) fashion, 7) film, video dan fotografi, 8) permainan interaktif, 9) musik, 10) seni pertunjukkan, 11) penerbitan dan percetakan, 12) layanan computer dan piranti lunak , 13) televisi dan radio , 14) riset dan pengembangan , 15) kuliner, dan 16) aplikasi dan game developer. Tetapi, tidak semua jenis ekonomi kreatif ini berkembang pesat di Indonesia. Ada pertumbuhan ekonomi kreatif yang relatif lambat.

Sejak ahli geologi Belanda Willem Hendrik de Greve menemukan endapan batubara di Sungai Batang Ombilin sekitar tahun 1867, Sawahlunto telah Dikenal sebagai kota penghasil batubara. Dengan berlalunya waktu produksi batu bara pun mengalami penurunan, sehingga aktivitas penambangan pun berhenti pada tahun 2004 Sejak aktivitas tambang di Sawahlunto berhenti, pemerintah kota Sawahlunto mulai mengembangkan ekonomi kreatif untuk membangkitkan kembali perekonomian masyarakatnya. Terbukti dengan didaulatnya Sawahlunto sebagai kota ekonomi kreatif terbaik pada tahun 2016 yang di selenggarakan oleh Sindo Weekly Government Award.

Dari ke 16 sub sektor ekonomi kreatif, tidak semua sub sektor ada di Kota Sawahlunto yang ada hanya seni pertunjukan, musik, kuliner, kriya, fashion, desain komunikasi visual, desain interior, photography, videografi, film, animasi, dan video, serta percetakan. Namun yang lebih diprioritaskan adalah seni pertunjukan, fashion, kuliner, dan kriya. Sedangkan yang lainnya masih dalam tahap pembinaan yang artinya belum memiliki dampak terhadap ekonomi. Ke empat sub sektor tersebut yang sedang gencar diusahakan pengembanganya oleh Dinas Pariwisata Pemuda dan Olahraga karena memang sub sektor sektor seni pertunjukan, fashion, kuliner dan kriya memiliki potensial yang besar untuk dikembangkan di Kota Sawahlunto.

Oleh karena itu penulis ingin melihat bagaimana implementasi strategi Dinas Pariwisata Pemuda dan Olahraga dalam mengembangkan ekonomi kreatif di Kota Sawahlunto.

\section{TINJAUAN PUSTAKA \\ Implementasi Strategi}

Wheelen-Hunger (2003: 296) mengemukakan bahwa implementasi strategi adalah untuk dapat melaksanakan 
banyak kegiatan dan pilihan yang diperlukan untuk perencanaan Implementasi strategi adalah proses mengubah rangkaian strategi dan aturan menjadi tindakan dengan merumuskan rencana, anggaran dan prosedur Implementasi Kunci sukses manajemen strategis.

Heide mengemukakan dalam Heene (2018: 181) bahwa kemampuan untuk berhasil mengimplementasikan suatu strategi dipengaruhi oleh beberapa faktor, yaitu:

1) Sistem informasi organisasi, Implementasi strategi yang berhasil membutuhkan aliran informasi yang relevan dan berkelanjutan yang mencakup semua bagian organisasi.

2) Kemampuan proses pembelajaran organisasi Implementasi strategi tidak hanya menuntut semua peserta memahami strategi, tetapi juga harus mampu mengembangkan pengetahuan dan keterampilan agar berhasil menerapkan strategi.

3) Pengalokasian fasilitas organisasi secara keseluruhan, Jika tidak cukup fasilitas, termasuk fasilitas yang disiapkan secara khusus, maka dapat dikatakan sulit untuk berhasil melaksanakan suatu strategi.

4) Struktur organisasi standar. Struktur standar organisasi akan berdampak tidak langsung pada implementasi strategi dengan mempengaruhi arus informasi, pemantauan dan proses pengambilan keputusan dalam organisasi.

5) Kebijakan manajemen sumber daya manusia organisasi, Keberhasilan penerapan strategi akan bergantung pada dedikasi masing-masing peserta yang bertanggung jawab untuk membuat strategi menjadi kenyataan.

6) Menggunakan pengaruh politik dalam organisasi, Ketika partisipan atau kelompok partisipan tertentu melihat strategi sebagai sesuatu yang mengurangi kekuatan atau status mereka, mereka akan menghambat implementasi.

7) Budaya organisasi, meliputi seluruh sistem kognitif, nilai dan pola perilaku yang melekat dalam organisasi. Strategi yang kurang dapat beradaptasi dengan budaya organisasi akan menyebabkan penolakan yang kuat dan menghambat upaya untuk mengimplementasikan strategi secara efektif.

\section{Konsep Manajemen Strategi}

Manajemen strategis Amirullah (2015: 1) pertama kali diperkenalkan pada awal 1960-an, ketika manajemen strategis mendapat perhatian luas dari semua lapisan masyarakat. Hal ini terlihat dari konsep dan teknik analisis yang digunakan sebagai alat utama pengambilan keputusan manajemen. Kebanyakan manajer tingkat perusahaan, level teknis atau tingkat fungsional percaya bahwa pemakaian konsep manajemen strategis bisa mengurangi ketidakpastian dan masalah yang semakin kompleks dalam bisnis.

Menurut definisi Pearce dan Robinson dalam Amirullah (2015: 5), manajemen strategis diartikan suatu rangkaian keputusan dan tindakan yang mengarah pada perumusan (pengembangan) dan implementasi (pencapaian) rencana yang bertujuan untuk mencapai tujuan perusahaan. Bozmen \& Straussman dalam Akdon (2011: 87) mengusulkan empat prinsip untuk menerapkan manajemen strategis di sektor publik, yaitu: a. perhatian jangka panjang b. Mengintegrasikan tujuan ke dalam hierarki yang jelas c. Sadarilah bahwa manajemen strategis membutuhkan disiplin dan komitmen untuk mencapai, bukan pemenuhan diri d. Pandangan eksternal tidak dapat diartikan sebagai adaptasi lengkap terhadap lingkungan, tetapi merupakan ekspektasi dari perubahan lingkungan.

Berdasarkan definisi manajemen strategi tersebut maka bisa disimpulkan bahwa manajemen strategi adalah rangkaian proses atau tahapan yang diorganisir oleh suatu organisasi untuk mencapai tujuan organisasi. Proses atau tahapan tersebut 
antara lain: analisis strategi proporsional, perumusan strategi yang sangat baik, dan implementasi strategi yang akurat. Dan terakhir nilai kontinuitas. Dalam performanya Manajemen strategis bertujuan agar manajer dapat menangani masalah spesifik perusahaan, sehingga mereka dapat lebih mudah menemukan peluang baru dan memperkirakan keuntungan yang dapat digunakan dan kerugian yang harus diperbaiki.

\section{Konsep Ekonomi Kreatif}

Menurut Presiden Susilo Bambang Yudhoyono dalam Agung Pascaseseno (2014), "Ekonomi kreatif adalah ekonomi gelombang keempat dan kelanjutan dari gelombang ekonomi ketiga. Arahnya Itu kreativitas, budaya, dan warisan budaya dan lingkungan. "Menurut penelitian Institute of Development Economics and Finance (2005), ekonomi kreatif adalah pengembangan transformasi hak atas kekayaan intelektual menjadi produk yang dapat dijual dengan nilai tambah berupa kreativitas, keterampilan, dan bakat pribadi.

John Howkins (2001) dalam (Moelyono) (2010:218) Ekonomi kreatif diartikan sebagai kegiatan ekonomi yang didasarkan pada kreativitas, budaya, warisan budaya, dan lingkungan di masa depan. Ekonom Amerika Richard Florida (2001) kemudian mengajukan konsep ini, dalam bukunya "The Creative Class and the Rise of Cities and the Creative Class", ia mengulas tentang industri kreatif dan kelas kreatif di masyarakat.

Ekonomi kreatif memiliki hubungan yang erat dengan industri kreatif, tetapi ruang lingkup ekonomi kreatif lebih luas dari pada industri kreatif. Landasan ekonomi kreatif terutama didasarkan pada tiga hal berikut: a. Kreativitas bisa diartikan sebagai keahlian untuk menghasilkan atau menciptakan sesuatu yang unik, segar dan diterima secara umum. b. Invention, istilah tersebut mendasarkan pada penciptaan suatu hal yang belum pernah ada, dan bisa dikatakan sebagai karya yang mempunyai kegunaan yang berbeda dengan yang lainnya. c. Inovasi adalah gagasan menggunakan penemuan yang ada untuk menghasilkan produk atau proses yang lebih baik, bernilai tambah dan bermanfaat atau transformasi gagasan berdasarkan kreativitas. (Rochmat: 2016).

\section{Konsep Pemerintah Daerah}

Pasal 18 UUD 1945 memberikan kekuasaan yang luas, dan bertanggung jawab kepada daerah, yang menjadi dasar hukum bagi pembentukan pemerintah daerah dan penyelenggaraan otonomi daerah. Saat menentukan kewenangan yang dipegang oleh masing-masing daerah, setelah dikurangi lima kekuasaan yang dimiliki oleh pemerintah pusat, maka kekuasaan daerah adalah sisa dari semua kekuasaan. Artinya, izin yang dimiliki suatu daerah tidak terbatas, sehingga setiap daerah dapat menggunakan izin sebanyakbanyaknya sesuai dengan kebutuhan dan kemampuan daerah yang bersangkutan.

Sedangkan dalam pemerintah daerah UU No. 23 Tahun 2014 tentang Pemerintah Daerah, adalah Gubernur, Bupati, atau Walikota, dan perangkat daerah lainnya, serta Ini merupakan bagian tak terpisahkan dari penyelenggaraan pemerintahan daerah. Ringkasnya, dalam pelaksanaan pemerintahan daerah sebagai urusan wajib pemerintah daerah, undang-undang ini telah merinci ketentuan dalam Pasal 12 ayat (2) UU No. 23 Thun 2014 Tentang pemerintah daerah.

Berikut ini peran konkrit yang dapat dilakukan oleh Pemerintah daerah dalam pengembangan ekonomi kreatif :

1) Katalisator dan Fasilitator

Pemerintah daerah seharusnya memberikan dorongan untuk mewujudkan ide-ide entitas ekonomi kreatif yang ada. Dan juga menyediakan sarana ataupun fasilitas untuk pengembangannya.

2) Sebagai Investor

Pemerintah daerah Harus bisa mengesahkan aset (gedung dan infrastruktur) yang sudah mereka miliki agar lebih efektif mendukung 
perkembangan ekonomi kreatif yang ada.

3) Urban Planner

Pemerintah daerah berperan sentral dalam menciptakan kota kreatif atau kawasan dan klaster kreatif. Karena hanya di kota atau daerah kreatif saja kreativitas bisa tumbuh dan berkembang.

4) Sebagai Konsumen

Pemerintah daerah jangan cuma mewajbkan masyarakat membeli produk kreatif yang dihasilkan oleh entitas ekonomi kreatif, namun pemerintah daerah harus mengutamakan pemanfaatan produk dan jasa lokal tersebut untuk memenuhi kebutuhannya.

5) Regulator dan advokat

Kekuasaan politik yang dimiliki oleh pemerintah daerah harus didistribusikan secara proporsional sesuai dengan kondisi yang menguntungkan bagi pengembangan ekonomi kreatif. Kebijakan pemerintah daerah yang inovatif juga dibutuhkan untuk menangani permasalahan yang muncul di masyarakat, daripada menimbulkan masalah baru.

\section{METODE PENELITIAN}

Penelitian ini merupakan penelitian kualitatif dengan metode deskriptif, dan pemilihan objek informasi dilakukan melalui teknik purposive sampling. Lokasi penelitian dilakukan di Dinas Pariwisata Pemuda dan Olahraga Kota Sawahlunto. Teknik pengumpulan data observasi, wawancara danstudi dokumentasi. Sedangkan untuk analisis data dilakukan dengan cara mengumpulkan data, reduksi data, menyajikan data dan menarik kesimpulan. Kemudian menggunakan teknik triangulasi untuk menguji keabsahan data.
HASIL DAN PEMBAHASAN

Implementasi Strategi Dinas Pariwisata Pemuda dan Olaraga Dalam Mengembangan Ekonomi Kreatif di Kota Sawahlunto

Wheelen-Hunger (2003: 296) mengemukakan bahwa implementasi strategi adalah untuk dapat melaksanakan banyak kegiatan dan pilihan yang diperlukan untuk perencanaan strategis Implementasi strategi adalah proses mengubah berbagai strategi dan kebijakan menjadi tindakan dengan merumuskan rencana, anggaran dan prosedur merupakan kunsi keberhasilan manajemen strategis.. Oleh karena itu, sesuai dengan tahapan implementasi strategi Wheelen dan Hunger, kita dapat melihat implementasi dari strategi pengembangan ekonomi kreatif di Kota Sawahlunto. Tahapan implementasi strategi meliputi tiga tahapan yaitu penentuan rencana, penetapan anggaran dan perumusan prosedur.

1) Program

Program merupakan salah satu variable penentu dalam kesuksesan implementasi strategi dalam pengembangan ekonomi kreatif ini. Dalam program memuat Rencana dan agenda kegiatan yang akan dilaksanakan oleh organisasi, rencana yang ditentukan penting untuk tujuan yang ingin dicapai oleh organisasi. Keberhasilan implementasi juga dilihat dari bagaimana suatu program itu dibuat, program yang dibuat dan direncanakan dengan baik juga akan menjadi penentu keberhasilan implementasi begitu juga sebaliknya program yang tidak direncanakan dan dibuat dengan baik akan menjadi pengahambat implementasi tersebut.

Beberapa program yang dijalankan oleh Dinas Pariwisata Pemuda dan Olahraga dalam mengembangkan ekonomi kreatif di Kota Sawahlunto, yang dinamakan dengan program "pengembangan ekonomi kreatif":

a. Meningkatkan kualitas sumber daya manusia di berbagai sektor dalam bentuk kegiatan workshop, dan pelatihan. 
b. Mefasilitasi sarana pendukung kegiatan ekonomi kreatif.

c. Memonitoring kegiatan pelaku ekonomi kreatif.

\section{2) Anggaran}

Anggaran dibutuhkan setelah program dikembangkan, anggaran juga merupakan sesuatu yang sa penting dalam pengimplementasian suatu program. Supaya program dapat berjalan dengan lancar tentu harus memiliki anggaran agar mampu mendrong pengoperasionalan suatu program. Menurut M. Nafarin (2012:19) menyatakan bahwa: "Anggaran adalah rencana tertulis yang berkaitan dengan kegiatan organisasi, dinyatakan secara kuantitatif dalam kurun waktu tertentu, biasanya dinyatakan dalam satuan moneter."

Berdasarkan temuan dilapangan anggaran yang disediakan oleh pemerintah daerah setiap tahunnya Rp.30.000.000, nantinya anggaran ini akan dialokasikam untuk workshop, pelatihan-pelatihan serta untuk sarana pendukung pengembangan ekonomi kreatif. Dan untuk pelaku ekonomi kreatifnya sendiri Dinas Pariwisata Pemuda dan Olahraga juga mendorong para pelaku ekonomi kreatif agar dapat memanfaatkan bantuan-bantuan yang ada dari pemerintah

\section{3) Prosedur}

Pada tahap prosedur ini tahap-tahap adalah bagaimana menyelesaikan pekerjaan di program yang dibuat, melalui suatu prosedur, dan memastikan bahwa pekerjaan dapat diselesaikan dengan benar dan hasilnya sesuai dengan harapan.

Berdasarkan temuan dilapangan ada beberapa tahapan yang dilakukan oleh Dinas Pariwisata Pemuda dan Olahraga dalam pengembangan ekonomi kreatif ini:

a. Melakukan pelatihan kepada para pelaku ekonomi kreatif, untuk lebih mengembangkan kreativitas para pelaku ekonomi kreatif.

b. Melakukan promosi-promosi usaha.

c. Mengevalusi pelaksanaan pengembangan ekonomi kreatif
Faktor apa saja yang mempengaruhi implementasi strategi pengembangan ekonomi kreatif di Kota Sawahlunto

1) Faktor Pendukung

Faktor pendukung adalah sesuatu hal yang sifatnya turut mendorong, menyokong, melancarkan dan membantu proses implementasi. Dalam implementasi strategi pengembangan ekonomi kreatif di Kota Sawahlunto ini didukung oleh beberapa faktor diantaranya:

a. Sawahlunto kaya dengan multi etniknya.

b. Berkembangnya pariwisata Sawahlunto yang mendukung adanya ekonomi kreatif.

c. Warisan budaya yang beranekaragam dan masih terpelihara sampai sekarang.

d. Peran aktif Dinas Pariwisata Pemuda dan Olahraga serta pelaku ekonomi kreatif.

2) Faktor Penghambat

Faktor penghambat merupakan hal yang dapat menghalangi pelaksanaan ataupun kemajuan suatu hal. Dalam implementasi strategi pengembangan ekonomi kreatif, Dinas Pariwisata Pemuda dan Olahraga menghadapi beberapa hambatan diantaranya :

a. Kemampuan sumber daya manusia yang masih rendah.

b. Pasar yang terbatas untuk penjualan produk.

c. Tenaga profesional yang masih kurang.

d. Keterbatasan sarana dan prasarana.

e. Masalah pendanaan ataupun modal

\section{Analisis SWOT}

Perencanaan strategi adalah gambaran kegiatan atau rencana kerja perusahaan atau organisasi. Melalui rencana yang mengidentifikasi upaya untuk mencapai tujuan bersama. Berikut Kekuatan, Kelemahan, Peluang dan Ancaman dalam implementasi strategi pengembangan ekonomi kreatif di Kota Sawahlunto. Faktor-faktor Strategi Eksternal : 


\section{Peluang (Opportunities) :}

a. Adanya perhatian yang lebih dari Dinas Pariwisata Pemuda dan Olaraga untuk pengembangan ekonomi kreatif.

b. Kota Sawahlunto pernah mendapatkan penghargaan sebagai Kota terbaik bidang ekonomi kreatif.

c. Hasil Produk ekonomi kreatif yang memiliki ciri khas.

d. Banyak konsumen yang tertarik dengan hasil produk ekonomi kreatif.

\section{Ancaman (Threats) :}

a. Perkembangan teknologi yang semakin canggih.

b. Harga bahan baku yang tidak stabil.

Faktor-faktor Strategi Internal :

\section{Kekuatan (Strenght) :}

a. Dari sisi sejarah Sawahlunto dikaruniai warisan budaya yang beranekaragam.

b. Berkembangnya sektor pariwisata di Kota Sawahlunto sangat mendukung keberadaan ekonomi kreatif.

c. Peran aktif dari Dinas Pariwisata Pemuda dan Olahraga serta pelaku ekonomi kreatif

\section{Kelemahan (weaknesses) :}

a. Kemampuan sumber daya manusia yang masih rendah.

b. Pasar yang terbatas untuk pemasaran.

c. Kurangnya tenaga yang profesional dimasing-masing bidang.

d. Keterbatasan sarana dan prasarana.

e. Masalah pendanaan ataupun modal.

Berdasarkan analisis SWOT, maka untuk terus mengembangkan ekonomi kreatif ini kedepannya pemerintah harus lebih mengembangkan lagi sumber daya manusianya agar lebih memiliki skill dan keterampilan yang mumpuni dibidangnya masing-masing, dan memperluas pasar melalui kemitraan, sehingga memperluas ruang lingkup pemasaran.

\section{PENUTUP}

Kesimpulan yang dapat diambil berdasarkan hasil penelitian dan pembahasan adalah sebagai berikut :

1) Dari hasil penelitian didapatkan temuan bahwa implementasi strategi Dinas Pariwisata Pemuda dan Olaraga dalam mengembangkan ekonomi kreatif di Kota Sawahlunto sudah cukup baik dalam pelaksanannya. Meskipun belum maksimal dalam proses implementasinya yang disebabkan oleh kendala yang terjadi baik internal maupun eksternalnya, implementasi ini diukur dari program, anggaran dan prosedur.

2) Faktor pendukung dan penghambat dalam implementasi strategi Dinas pariwisata Pemuda dan Olahraga dalam mengembangkan ekonomi kreatif di Kota Sawahlunto, beberapa faktor pendukung diantaranya, Sawahlunto kaya dengan multi etniknya, berkembangnya pariwisata Sawahlunto yang mendukung adanya ekonomi kreatif, warisan budaya yang beranekaragam dan masih terpelihara sampai sekarang, dan peran aktif Dinas Pariwisata Pemuda dan Olaraga serta pelaku ekonomi kreatif. Serta yang menjadi faktor penghambat dalam implementasi strategi ini adalah kemampuan sumber daya manusia yang masih rendah, pasar yang terbatas untuk penjualan produk, tenaga profesional yang masih kurang, keterbatasan sarana dan prasarana dan masalah pendanaan ataupun modal.

3) Berdasarkan analisis SWOT implementasi strategi Dinas Pariwisata Pemuda dan Olahraga dalam mengembangkan ekonomi kreatif di Kota Sawahlunto adalah lebih mengembangkan lagi sumber daya manusianya agar para pelaku ekonomi kreatif ini lebih memiliki keterampilan yang mumpunni dibidangnya masingmasing serta memperluas pasar melalui kemitraan, sehingga memperluas ruang lingkup pemasaran. 


\section{DAFTAR KEPUSTAKAAN}

Moelyono, Mauled. Menggerakkan Ekonomi Kreatif Antara Tuntutan dan Kebutuhan. Jakarta: PT Raja Grafindo Persada, 2010.

Akdon. 2011. Strategic Management For Education Management (Manajemen strategik untuk Manajemen Pendidikan). Bandung. Alfabeta.

Amirullah. 2015. Pengantar Manajemen. Jakarta : Mitra Wacana Media.

Heene, Aime dkk, 2010. Manajemen Strategik Keorganisasian Publik. Bandung. Refika Aditama.

Hunger, J. David dan Wheelen, Thomas L. Manajemen Strategis, Yogyakarta: Andi, 2003.

Noviyanti, R. (2017). Peran Ekonomi Kreatif Terhadap Pengembangan Jiwa Enterpreneurship Di Lingkungan Pesantren. Jurnal Penelitan Ilmiah Intaj, 78-80.

Nurul Istifadah, H. T. (2017). Kreativitas Dan Inovasi Pada Industri Kreatif Untuk Meningkatkan Daya Saing Dan Kesinambungan Pertumbuhan Ekonomi. Conference on Management and Behavioral Studies, 90-91.

Irawan, A. (2015). Ekonomi Kreatif Sebagai Solusi Mensejahterakan Masyarakat Dalam Meningkatkan Tingkat Perekonomian. Seminar Nasional Ekonomi dan Bisnis, 1-3.

Azizah, S. N. (2017). Pengembangan Ekonomi Kreatif Berbasis Kearifan Lokal Pandanus. Jurnal Aplikasi Ilmuilmu Agama, 73-74.

Undang-undang Nomor 23 tahun 2014 Tentang Pemerintah Daerah. 